Sains Malaysiana 50(2)(2021): 525-536

http://dx.doi.org/10.17576/jsm-2021-5002-23

\title{
Effects of \%FIMA on Storage-Safety Parameters of Spent Fuel from Experimental Pebble-Bed Reactor
}

(Kesan \%FIMA terhadap Parameter Keselamatan Penyimpanan Bahan Bakar Terpakai daripada Uji Kaji Reaktor Pengalas Kerikil)

\author{
Aisyah Aisyah, Mirawaty Mirawaty, Dwi Luhur Ibnu Saputra, Risdiyana Setiawan, Pungky Ayu \\ ARTIAN, RATIKO RATIKO* \& NASRUDDIN NASRUDDIN
}

\begin{abstract}
The back end of the utilization of nuclear technology is safety and management of spent fuel, which is a key element contributing to the success of the nuclear power plant program. Indonesia's National Nuclear Energy Agency resolved to establish an experimental power reactor, called RDE, as a nuclear power plant demo. The fuel of this reactor is similar to that of German's experimental pebble-bed reactor (PBR), Arbeitsgemeinschaft Versuchsreaktor(AVR). In this study, the spent fuel of AVR was studied to obtain the safety parameter data for storage of RDE spent fuel by varying the fission in the initial metallic atoms (\%FIMA). These parameters that must be studied include the radioactivity, decay heat, proliferation threats of both ${ }^{239} \mathrm{Pu}$ and ${ }^{235} \mathrm{U}$, and the presence of ${ }^{137} \mathrm{Cs}$, a dangerous fission product that can escape from damaged spent fuels. The calculation was conducted by ORIGEN 2.1. The result of the study demonstrates a higher $\%$ FIMA indicates a higher safety level that is required since the activity and decay heat of the spent fuel will increase and, as will be the total amounts of ${ }^{239} \mathrm{Pu}$ and ${ }^{137} \mathrm{Cs}$. However, the ${ }^{235} \mathrm{U}$ amount will decrease. For a 100 years storage of spent fuel, the optimum \%FIMA is 8.2 with a canister capacity of 1,900 pebbles. Further, the activity and decay heat of the spent nuclear fuel are $2.013 \times 10^{13} \mathrm{~Bq}$ and $6.065 \mathrm{~W}$, respectively. The activities of ${ }^{239} \mathrm{Pu},{ }^{137} \mathrm{Cs}$, and ${ }^{235} \mathrm{U}$ are $5.187 \times$ $10^{11}, 7.100 \times 10^{12}$, and $7.339 \times 10^{7} \mathrm{~Bq}$, respectively.
\end{abstract}

Keywords: \%FIMA; pebble-bed reactor; spent fuel; spent-fuel storage safety

\section{ABSTRAK}

Kesan jangka panjang manfaat daripada teknologi nuklear adalah keselamatan dan pengurusan bahan bakar terpakai yang merupakan unsur utama kepada kejayaan program loji tenaga nuklear. Badan Tenaga Nuklir Nasional (BATAN) Indonesia memutuskan untuk membangun reaktor tenaga uji kaji yang disebut sebagai RDE sebagai demo loji tenaga nuklear. Bahan bakar reaktor ini mirip dengan reaktor pengalas kerikil uji kaji Jerman (PBR), Arbeitsgemeinschaft Versuchsreaktor (AVR). Dalam kajian ini, bahan bakar terpakai AVR dikaji untuk mendapatkan data parameter keselamatan untuk penyimpanan bahan bakar terpakai RDE dengan mengubah pembelahan pada atom logam awal (\%FIMA). Parameter ini yang mesti dikaji meliputi radioaktif, panas pereputan, ancaman percambahan kedua-dua ${ }^{239} \mathrm{Pu} d a{ }^{235} \mathrm{U}$ dengan kehadiran ${ }^{137} \mathrm{C}$, produk pembelahan berbahaya yang dapat melepaskan diri daripada bahan bakar terpakai yang rosak. Pengiraan dilakukan dengan menggunakan ORIGEN 2.1. Hasil kajian menunjukkan \% FIMA yang lebih tinggi menyumbang kepada tahap keselamatan yang lebih tinggi yang diperlukan kerana aktiviti dan haba pereputan bahan bakar habis akan meningkat seperti jumlah keseluruhan ${ }^{239} \mathrm{Pu}$ dan ${ }^{137} \mathrm{C}$. Walau bagaimanapun, jumlah ${ }^{235} \mathrm{U}$ akan menurun. Untuk penyimpanan bahan bakar terpakai selama 100 tahun, \%FIMA optimum ialah 8.2 dengan kapasiti kanister 1,900 kerikil. Selanjutnya, aktiviti dan haba pereputan bahan bakar terpakai nuklear masing-masing adalah $2.013 \times 10^{13}$ Bq dan $6.065 \mathrm{~W}$. Aktiviti ${ }^{239} \mathrm{Pu},{ }^{137} \mathrm{Cs}$ dan ${ }^{235} \mathrm{U}$ masing-masing adalah $5.187 \times 10^{11}, 7.100 \times 10^{12}$ dan $7.339 \times 10^{7} \mathrm{~Bq}$.

Kata kunci: \%FIMA; bahan bakar terpakai; keselamatan penyimpanan bahan bakar terpakai; reaktor pengalas kerikil 


\section{INTRODUCTION}

The International Atomic Energy Agency (IAEA) predicted that the number of nuclear power plants will grow by $42 \%$ in 2030 and $123 \%$ in 2050 (Pratomo 2017). This statement corresponds with the views of some countries regarding the global interests in nuclear power plants. Further, the National Nuclear Energy Agency of Indonesia (BATAN) aims to build a nuclear power plant in the future (Ratiko et al. 2020). To prepare for the establishment of nuclear power plants, in 2014, BATAN resolved to build an experimental nuclear power plant, named Reaktor Daya Eksperimen (RDE), to demonstrate a prototype of the nuclear reactor technology and exhibit their capacity to construct and operate a secured and safe nuclear power plant (Liem et al. 2018, 2017).

This experimental power plant employed a pebblebed reactor, high-temperature gas-cooled reactor (HTGR), graphite moderator and fuel, and thermal power of $10 \mathrm{MW}$ (Setiadipura et al. 2018). HTGR is a fourth-generation reactor, designed to feature a passive safety system that is safe, however (Aisyah et al. 2019; Setiadipura et al. 2015). As a reference to this work, we studied a German HTGR, Arbeitsgemeinschaft Versuchsreaktor (an experimental PBR, AVR), to compile the data on the safety of the storage of RDE spent fuel. In Germany, the operation of AVR had stopped since 1988 after 21 years (Artiani et al. 2019; Sen \& Viljoen 2012). AVR utilizes a pebble-shaped nuclear fuel with a tristructural isotropic (TRISO)-coated particle that is the same as that of the RDE nuclear fuel (Aisyah et al. 2019).

AVR utilizes kernel fuel in the form of pebble-shaped low-enriched $\mathrm{UO}_{2}(<20 \%)$ with a TRISO-coated particle. A TRISO layer consists of four sublayers (coats), namely, the low-density pyrolitic carbon (PyC), high-density inner pyrolitic carbon (IPyC), silicon carbide (SiC), and high-density outer pyrolitic carbon (OPyC) coats. These four layers, listed from the innermost to the outermost, maintain the fuel integrity, such as its structural strength, dimensional stability, as well as functioning as the main barriers to the emission of fission products from the fuel (Demkowicz et al. 2018; Dewita 2008; Dulera et al. 2017; Ji et al. 2014; Kania et al. 2013). However, during the operation, the TRISO layer may be damaged due to friction between moving pebbles in the reactor core, especially if the fuel operates with high fission in the initial metallic atoms (\%FIMA). A nuclear fuel, at high \%FIMA, is one, which is retained in the reactor core for a prolonged period.

Several crucial points regarding the safety parameters of prolonged spent-fuel storage in a dry cask, such as the safety of the radioactivity and decay heat and the proliferation, as well as the release of volatile radionuclide fission products from the canister to the environment, should be considered. The safety of the specific activity of the radionuclide in relation to the increased \%FIMA of spent fuel requires further studies. The operation of a reactor, at high \%FIMA, will generate many fission reactions, which will produce spent fuel with increased activity and decay heat. Moreover, to ensure the safety of spent-fuel storage, the amount of the activity and decay heat, loaded into the canister, should be restricted. Put differently, the canister should be prevented from overloading the spent-fuel pebbles with increased \%FIMA.

An increased \%FIMA in the operation of a nuclear reactor may increase the transmutation reaction of ${ }^{238} \mathrm{U}$ into ${ }^{239} \mathrm{Pu}$. Thus, a higher \%FIMA will yield more ${ }^{239} \mathrm{Pu}$. Notably, ${ }^{239} \mathrm{Pu}$ is a fissile radionuclide with a long halflife and high toxicity and can be abused, as a raw material of a nuclear weapon (Prasad et al. 2015; Serfonteina et al. 2014). However, Indonesia has signed a Nuclear NonProliferation Treaty (NPT), restricting its ownership of a nuclear weapon. Therefore, the safety, regarding both the possibility of nuclear proliferation and the presence of ${ }^{239} \mathrm{Pu}$ in spent fuel, must be considered. Consequently, the amount of ${ }^{239} \mathrm{Pu}$ in spent fuel must be calculated (Kim et al. 2015; Serfonteina et al. 2014). Conversely, the ${ }^{235} U$, which is remained in spent fuel must also be considered in terms of proliferation.

The increase in \%FIMA during the operation of the reactor will also increase the fission of ${ }^{235} \mathrm{U}$, eventually increasing the amount of the radionuclides of the fission product in spent fuel (Kim et al. 2015). The damages of some TRISO coats in spent fuel will enable the escape of the radionuclides of the fission products, especially the volatile ones, such as ${ }^{137} \mathrm{Cs}$, from the spent fuel and canister. Since the radionuclides of the fission product, which are released into the environment, would result in a radiologic impact on the society and environment, it is vital to know the amount of the increased radionuclide of the fission product due to increased \%FIMA (Aisyah et al. 2019). Recently, some countries tend to manage their spent fuel by storing it for an extended period because they lack disposal facilities.

There are some studies on the interim storage of spent fuel. Ternovykh et al. (2017), calculated the decay heats of actinide and the fission product of the spent fuel of a VVER-1000 reactor-type, stored for an extended period. Ratiko et al. (2019, 2018), Wang and Yang (2017), and Wang et al. (2013) studied the natural heat removal from spent fuel in its interim storage (dry storage) and the natural airflow equation caused by the temperature difference between the two connected spaces (in this case, between the inside and outside of the dry storage). 
Moreover, Wu et al. (2019), studied the impacts of burnup on the storage criticality of spent fuel in a China-based PBR. Serfontein et al. (2014), studied the reduction of proliferation risk by burning ${ }^{239} \mathrm{Pu}$ in a modular $\mathrm{PBR}$ of a demonstration power plant. Husnayani $(2016,2015)$ and Husnayani and Udiyani (2018) studied the inventory analysis of the fission product of HTGR fuel and the characteristics of the spent fuel in an experimental power reactor. Moreover, Aisyah et al. (2019), characterized the radionuclide of the spent fuel of an experimental PBR.

Generally, these scientists only studied the characteristics of the spent fuels of HTGRs, at a certain burnup, without relating them to their proliferation. In fact, the design and safety of dry storage for spent fuel really depend on the characteristics of the spent fuel. Therefore, we conducted a study on the storage-safety parameters, such as the types of radionuclide, specific activity, decay heat, and tendency to release a volatile fission product to the environment, of AVR spent fuel, at various \%FIMA, as well as their relations to safety from any proliferation threat. We studied the safety of spent-fuel storage in dry storage for 100 years.

\section{METHODS}

One of storage-safety parameters that contributes to spent-fuel safety management is the characteristics of the radionuclides of the spent fuel. Therefore, the characterization of spent fuel was also studied. This study included the types of radionuclide contents, the activity of the radionuclides in the spent fuel, the decay heat, activities of ${ }^{235} \mathrm{U}$ and ${ }^{239} \mathrm{Pu}$ regarding possible proliferation, and the activity of ${ }^{137} \mathrm{Cs}$ that could escape from the spent nuclear fuel.

The characteristics of spent fuel were obtained by calculating them with the ORIGEN 2.1 computer program or Oak Ridge isotope generation and depletion code (version 2.1), assuming that there were decay heat and radionuclide formation in the spent fuel. This was calculated, employing equation (1) (Aisyah et al. 2019; Hadad et al. 2015):

$$
\begin{aligned}
\frac{\mathrm{d} x_{i}}{d t}= & \sum_{\mathrm{j}=1}^{\mathrm{N}} l_{i j} \lambda_{\mathrm{i}} \chi_{\mathrm{j}}-\emptyset \sum_{k=\mathrm{l}}^{N} \mathrm{f}_{\mathrm{ik}} \sigma_{\mathrm{k}} \chi_{\mathrm{k}}- \\
& \left(\lambda_{\mathrm{i}}+\emptyset \sigma_{\mathrm{i}}+\mathrm{r}_{\mathrm{i}}\right) \chi_{\mathrm{i}}+F_{i}, i=1 \ldots, N
\end{aligned}
$$

where $x_{i}$ is the atomic density of nuclide $i\left(\right.$ atom $\left./ \mathrm{cm}^{3}\right) ; N$ is the number of nuclides (atom); $l_{i j}$ is the fraction of the radioactive disintegration by nuclide $j$, which resulted in the nuclide $i$ formation (fractional); $\lambda_{i}$ is the radioactive decay constant $\left(\mathrm{sec}^{-1}\right), \phi$ is the space and energyaveraged neutron flux $\left(\mathrm{n} / \mathrm{cm}^{2} \mathrm{sec}\right) ; f_{i k}$ is the fraction of the neutron absorbed by nuclide $\mathrm{k}$, resulting in the formation of nuclide $i$ (fractional); $\sigma_{k}$ is the spectrum-averaged neutron absorption cross-section of nuclide $k$ (barn); $r_{i}$ is the continuous removal rate of nuclide $i$ from the system (atom $/ \mathrm{sec}$ ); and $F_{i}$ is the continuous feed rate of nuclide $i$ (atom $/ \mathrm{sec})$.

ORIGEN 2.1 requires a data library to conduct the calculation. An important data library, employed to calculate the radionuclide, activity, and decay heat, is the fission yield data. Fission yield data could be generated, employing the mass distribution curve, which consisted of symmetric and asymmetric parts (Gil et al. 2017).

The calculations, employing ORIGEN 2.1, require the input parameters, such as the type, operation, and fuel of the reactor. In this study, the calculation was based on the pebble-bed of AVR with thermal power of $46 \mathrm{MW}$; various burnups, stated at \%FIMA (Kim et al. 2015) of $1.7,3.3,4.5,6.6,8.2,11.4$, and 14.5; and pebble-type fuel with a TRISO coat. Moreover, the calculation was performed for 100 years of decay. It was assumed that each pebble was imposed on irradiation with an average specific power of $1.2 \times 10^{-4} \mathrm{MW}$. The pebble consisted of a kernel in the forms of $\mathrm{UO}_{2}$ with $5 \mathrm{~g}$ of $17 \%$-enriched ${ }^{235} \mathrm{U}$ and TRISO coats, consisting of IPyC, SiC, and OPyC, whose thicknesses were 0.004, 0.0035, and 0.004 $\mathrm{cm}$, respectively, and densities of $1.9,3.18$, and $1.9 \mathrm{~g} / \mathrm{cm}^{3}$, respectively. The total weight of one pebble was 200.945 $\mathrm{g}$, consisting of $0.0002 \mathrm{~g}$ of ${ }^{234} \mathrm{U}, 0.749 \mathrm{~g}$ of ${ }^{235} \mathrm{U}, 3.657 \mathrm{~g}$ of ${ }^{238} \mathrm{U}, 0.593 \mathrm{~g}$ of ${ }^{16} \mathrm{O}, 195.538 \mathrm{~g}$ of ${ }^{12} \mathrm{C}$, and $0.407 \mathrm{~g}$ of ${ }^{28} \mathrm{Si}$ (Artiani et al. 2019).

From the calculation result obtained by ORIGEN 2.1, hundreds of radionuclides were obtained. However, the radionuclides, which greatly contributed to the safety of the spent fuel storage, were selected. The selections were based on the half-life and clearance levels of the radionuclides, hence the characteristics of the spent fuel should only be the presence of radionuclides possessing a long half-life and a high specific activity.

The design of the dry cask, for the storage of the fuel, consisted of two canisters. The capacity of each canister was 950 pebbles, thus the dry cask could be loaded with 1,900 pebbles. Here, the activity of the radionuclides in one canister was calculated for a 100 years period. The spent-fuel pebble was loaded into the canister after six years of discharge from the reactor core. The required characteristics of the activity and decay heat are shown in Table 1 (Verfondern n.d.). 
TABLE 1. Required AVR spent-fuel characteristics in one dry storage canister (Verfondern n.d.)

\begin{tabular}{cc}
\hline Parameter & Six years decay \\
\hline Content & 950 fuel spheres \\
Total activity & $5 \times 10^{14} \mathrm{~Bq}$ \\
Surface dose power & $40 \mathrm{~Gy} \mathrm{~h}^{-1}$ \\
Thermal power & $60 \mathrm{~W}$ \\
Mass & $350 \mathrm{~kg}$ \\
\hline
\end{tabular}

\section{RESULTS AND DISCUSSION}

CHARACTERIZATION OF THE SPENT FUEL AND ITS LOADING INTO THE CANISTER

The safe loading of the spent fuel into the canister required the characteristic data of the spent fuel that had been stored after six years of discharge from the reactor core, at various \%FIMA. The calculation results of the spentfuel characteristics, including the type and content of its activation radionuclide, actinide and its daughter, a fission product, specific activity, and decay heat are shown in Tables 2 to 5. Table 2 shows the radionuclide of activation product, specific activity and decay heat contents.

TABLE 2. Effects of \%FIMA on the characteristics of the activation product radionuclides in spent fuel that had been stored after six years of discharge from the reactor

\begin{tabular}{|c|c|c|c|c|c|c|c|}
\hline \multirow{2}{*}{ Characteristics } & \multicolumn{7}{|c|}{$\%$ FIMA } \\
\hline & 1.7 & 3.3 & 4.5 & 6.6 & 8.2 & 11.4 & 14.5 \\
\hline Specific activity $(\mathrm{Bq} / \mathrm{g})$ & $8.84 \times 1^{0} 3$ & $1.89 \times 10^{4}$ & $4.00 \times 10^{4}$ & $7.65 \times 10^{4}$ & $2.22 \times 10^{5}$ & $3.72 \times 10^{6}$ & $8.89 \times 10^{7}$ \\
\hline Decay heat $(\mathrm{W} / \mathrm{g})$ & $7.3 \times 1^{0-1} 1$ & $1.44 \times 10^{-10}$ & $2.56 \times 10^{-10}$ & $3.90 \times 10^{-10}$ & $7.36 \times 10^{-10}$ & $5.04 \times 10^{-9}$ & $8.69 \times 10^{-8}$ \\
\hline $\begin{array}{l}\text { Types of the } \\
\text { radionuclides }\end{array}$ & \multicolumn{7}{|c|}{${ }^{3} \mathrm{H},{ }^{14} \mathrm{C},{ }^{10} \mathrm{Be}$} \\
\hline
\end{tabular}

Table 2 shows that the increase in \%FIMA corresponded to the increases in the specific activity and the decay heat, although the activation product radionuclidetypes were similar. The radionuclides were formed from the impurities contained in the helium cooler and graphite moderator that were activated by the neutrons. A higher $\%$ FIMA resulted in the prolonged irradiation of the fuel, causing that more impurities could react with the neutrons, thereby increasing the specific activity and decay heat. Three types of significant radionuclides, namely tritium $\left({ }^{3} \mathrm{H}\right)$ with a half-life of 12.35 years, carbon $\left({ }^{14} \mathrm{C}\right)$ with a half-life of 5,730 years, and beryllium $\left({ }^{10} \mathrm{Be}\right)$ with a halflife of $1.3 \times 10^{6}$ years, were obtained (Aisyah et al. 2019; Sartori 2013). The radionuclides were selected based on 
their half-lives and clearance levels. ${ }^{14} \mathrm{C}$ is a radionuclide, which results from neutrons activations of the ${ }^{14} \mathrm{~N}$ and ${ }^{13} \mathrm{C}$, from the impurities that originate from the helium cooler (CRWM 2014). Moreover, ${ }^{3} \mathrm{H}$ is an important radioactive material that requires much attention because it could penetrate metallic materials. The penetration of a heat exchanger by ${ }^{3} \mathrm{H}$ results in the formation of hydrogen gas. In AVR, ${ }^{3} \mathrm{H}$ was generated from the activations of boron and lithium, contained in the graphite, and those of the impurities, contained in helium, such as ${ }^{3} \mathrm{He}, \mathrm{CH}_{4}$, water vapor, and hydrogen (CRWM 2014).

At the lowest \%FIMA, i.e. 1.7, and after six years of storage, the specific activity of the radionuclides generated from the activation product is $8.84 \times 10^{3} \mathrm{~Bq}$ $\mathrm{g}^{-1}$, and the decay heat is $7.3 \times 10^{-11} \mathrm{~W} \mathrm{~g}^{-1}$. However, at $\%$ FIMA of 14.5 , the specific activity is $8.89 \times 10^{7} \mathrm{~Bq} \mathrm{~g}^{-1}$, and the decay heat is $8.69 \times 10^{-8} \mathrm{~W} \mathrm{~g}^{-1}$. The specific activity increased by $10^{4}$ orders and the decay heat increased by $10^{3}$ orders.

Actinide and its daughters, which are contained in the spent fuel, were generated from the transmutation reaction of ${ }^{238} \mathrm{U}$ by the neutrons in the fuel. As stated, the radionuclide was selected based on its half-life and clearance level and the radionuclide type was obtained, as shown in Table 3. Therein, the increased specific activity and decay heat are shown. However, the types of actinides and their daughters are similar to those of the others, at an increased \%FIMA.

TABLE 3. Effects of \%FIMA on the characteristics of the actinide radionuclides and their daughters in the spent fuel that had been stored after six years of discharge from the reactor

\begin{tabular}{|c|c|c|c|c|c|c|c|}
\hline \multirow{2}{*}{ Characteristics } & \multicolumn{7}{|c|}{$\%$ FIMA } \\
\hline & 1.7 & 3.3 & 4.5 & 6.6 & 8.2 & 11.4 & 14.5 \\
\hline Specific activity (Bq/g) & $1.23 \times 10^{8}$ & $6.85 \times 10^{8}$ & $2.63 \times 10^{9}$ & $6.15 \times 10^{9}$ & $1.60 \times 10^{10}$ & $4.55 \times 10^{10}$ & $6.24 \times 10^{10}$ \\
\hline Decay heat (W/g) & $1.78 \times 10^{-5}$ & $4.00 \times 10^{-5}$ & $8.59 \times 10^{-5}$ & $1.54 \times 10^{-4}$ & $3.51 \times 10^{-4}$ & $4.43 \times 10^{-3}$ & $3.86 \times 10^{-2}$ \\
\hline $\begin{array}{l}\text { Types of the } \\
\text { radionuclides }\end{array}$ & \multicolumn{7}{|c|}{${ }^{234} \mathrm{U},{ }^{235} \mathrm{U},{ }^{238} \mathrm{U},{ }^{238} \mathrm{Pu},{ }^{239} \mathrm{Pu},{ }^{240} \mathrm{Pu},{ }^{241} \mathrm{Pu},{ }^{241} \mathrm{Am}$} \\
\hline
\end{tabular}

An increased \%FIMA resulted in the transmutation of more ${ }^{238} \mathrm{U}$ into actinide. This resulted in increases in the specific activity and decay heat, as well as resulting in a decrease in ${ }^{238} \mathrm{U}$. The actinide and its daughter are radionuclides with very long half-lives. The longest is ${ }^{238} \mathrm{U}$ in the spent fuel, i.e., it is not fissile, with a half-life of billions of years. There are eight types of actinides and their daughters in the spent fuel stored after six years of discharge from reactor, namely ${ }^{234} \mathrm{U},{ }^{235} \mathrm{U},{ }^{238} \mathrm{U},{ }^{238} \mathrm{Pu},{ }^{239} \mathrm{Pu}$, ${ }^{240} \mathrm{Pu},{ }^{241} \mathrm{Pu}$, and ${ }^{241} \mathrm{Am}$. Their half-lives are $2.48 \times 10^{5}, 7.04$ $\times 10^{8}, 4.47 \times 10^{9}, 88,2.41 \times 10^{4}, 6.5 \times 10^{3}, 14.4$, and $4.32 \times$
$10^{2}$ years, respectively. At $1.7 \%$ FIMA, the specific activity of the actinide and its daughter is $1.23 \times 10^{8} \mathrm{~Bq} \mathrm{~g}^{-1}$ and the decay heat is $1.78 \times 10^{-5} \mathrm{~W} \mathrm{~g}^{-1}$. Moreover, at $14.5 \%$ FIMA, its specific activity is $6.24 \times 10^{10} \mathrm{~Bq} \mathrm{~g}^{-1}$, and its decay heat is $3.86 \times 10^{-2} \mathrm{~W} \mathrm{~g}^{-1}$. The specific activity increased by $10^{2}$ orders while the decay heat increased by $10^{3}$ orders.

The fission of ${ }^{235} \mathrm{U}$ with the neutrons generated $\sim 168$ types of radionuclides, as fission products, that are generally gamma-transmitting with high decay heat The selection of the radionuclides is based on their halflives and clearance levels, resulting in fission products, as shown in Table 4.

TABLE 4. Effects of \%FIMA on the characteristics of the radionuclide fission products in the spent fuel that had been stored after six years of discharge from the reactor

\begin{tabular}{|c|c|c|c|c|c|c|c|}
\hline \multirow{2}{*}{ Characteristics } & \multicolumn{7}{|c|}{$\%$ FIMA } \\
\hline & 1.7 & 3.3 & 4.5 & 6.6 & 8.2 & 11.4 & 14.5 \\
\hline Specific activity $\left(\mathrm{Bq} \mathrm{g}^{-1}\right)$ & $2.31 \times 10^{9}$ & $4.55 \times 10^{9}$ & $7.93 \times 10^{9}$ & $1.16 \times 10^{10}$ & $1.94 \times 10^{10}$ & $5.68 \times 10^{10}$ & $1.27 \times 10^{11}$ \\
\hline Decay heat $(\mathrm{W} / \mathrm{g})$ & $1.78 \times 10^{-5}$ & $1.25 \times 10^{-4}$ & $2.40 \times 10^{-4}$ & $3.88 \times 10^{-4}$ & $7.69 \times 10^{-4}$ & $3.87 \times 10^{-3}$ & $1.80 \times 10^{-2}$ \\
\hline $\begin{array}{l}\text { Types of the } \\
\text { radionuclides }\end{array}$ & \multicolumn{7}{|c|}{${ }^{85} \mathrm{Kr},{ }^{90} \mathrm{Sr},{ }^{134} \mathrm{Cs},{ }^{137} \mathrm{Cs},{ }^{147} \mathrm{Pm},{ }^{151} \mathrm{Sm},{ }^{154} \mathrm{Eu},{ }^{155} \mathrm{Eu}$} \\
\hline
\end{tabular}


Table 4 shows the dominant radionuclides of the fission products in the spent fuel, at various \%FIMA, that was stored after 6 years of discharge from the reactor core. The specific activity increased with increasing \%FIMA. This is because more uranium nuclide reacted with the neutrons, thus, forming fission products with higher specific activities and decay heats. The formed fission products are ${ }^{85} \mathrm{Kr},{ }^{90} \mathrm{Sr},{ }^{134} \mathrm{Cs},{ }^{137} \mathrm{Cs},{ }^{147} \mathrm{Pm},{ }^{151} \mathrm{Sm},{ }^{154} \mathrm{Eu}$, and ${ }^{155} \mathrm{Eu}$ with half-lives of 10.756, 29.1, 2.065, 30.167, 2.623, $88.84,8.593$, and 4.761 years, respectively. During the operation of AVR with spent fuel of $1.7 \%$ FIMA, stored after six years of discharge from the reactor, the specific activity of the fission products is $2.31 \times 10^{9} \mathrm{~Bq} \mathrm{~g}^{-1}$ and its decay heat is $7.69 \times 10^{-4} \mathrm{~W} \mathrm{~g}^{-1}$. Moreover, at $14.5 \%$ FIMA, its specific activity is $1.27 \times 10^{11} \mathrm{~Bq} \mathrm{~g}^{-1}$ and its decay heat is $1.78 \times 10^{-5} \mathrm{~W} \mathrm{~g} \mathrm{~g}^{-1}$. The specific activity increased in $10^{2}$ orders while the decay heat increased in $10^{3}$ orders.

To achieve the safety requirements of loading the spent fuel into the canister, as shown in Table 1, the total activity and decay heat of the activation products, actinides, and fission products in the canister containing 950 spent-fuel pebbles and their effects on \%FIMA were calculated and shown in Table 5.

TABLE 5. Effects of \%FIMA on the activity and decay heat of the spent-fuel that had been stored after six years of discharge from the reactor

\begin{tabular}{c|c|c|c|c|c|c|c}
\hline \multirow{2}{*}{ Characteristics } & \multicolumn{7}{|c}{ \%FIMA } \\
\cline { 2 - 8 } & 1.7 & 3.3 & 4.5 & 6.6 & 8.2 & 11.4 & 14.5 \\
\hline Spec. activity (Bq) & $1.77 \times 10^{13}$ & $3.70 \times 10^{13}$ & $7.09 \times 10^{13}$ & $1.14 \times 10^{14}$ & $2.16 \times 1^{01} 4$ & $6.25 \times 10^{14}$ & $1.20 \times 10^{15}$ \\
Decay heat (W) & 1.25 & 2.55 & 4.66 & 7.17 & 13.00 & 58.80 & 263.00 \\
\hline
\end{tabular}

Table 5 indicates that a higher \%FIMA could result in higher activity and decay heat. For the spent fuel of the AVR with 8.2\%FIMA, the specific activity in one canister was $\sim 50 \%$ of the required activity as shown in Table 1. Therefore, at $8.2 \%$ FIMA, one dry storage could be loaded with two canisters with $2 \times 950$ spent-fuel pebbles. However, at $11.4 \%$ FIMA, the decay heat, loaded into one canister would exceed the maximum required heat, indicating that one canister could only be loaded with $<$ 950 spent-fuel pebbles. Therefore, with spent-fuel pebbles of high \%FIMA, such as 14.5, the capacity of the canister would be lowered and it less-economical. Therefore, regarding the safe loading of spent fuel into the canister, the fuel with \%FIMA of 8.2 demonstrated more advantages because a double of the required capacity, i.e. 1,900 spentfuel pebbles, could be loaded into one canister. Moreover, based on the requirements, the canister could only be loaded with 950 spent-fuel pebbles. When observing its decay heat, the spent fuel with 8.2\%FIMA, based on the requirements of AVR, the canister could be loaded with 4 $\times 950$ spent-fuel pebbles, although this condition did not meet the requirements of its activity.

A low \%FIMA demonstrated advantages than the high ones. Low \%FIMA exhibited low spent-fuel activity and decay heat and the canister could be loaded with $>$ 950 pebbles. Moreover, for the high \%FIMA, the spent fuel possessed high decay heat and the canister exceeded the requirement for maximum heat could only be loaded by $<950$ pebbles. However, this condition is lesseconomical. Nevertheless, at low \%FIMA, the spent fuel contained relatively high ${ }^{235} \mathrm{U}$ residues, which resulted in the increased operating cost of the reactor because of its fuel requirements. Conversely, at high \%FIMA, the utilization of ${ }^{235} \mathrm{U}$, as fuel, would be more economical since it contained fewer residues of ${ }^{235} \mathrm{U}$. Based on the calculation, the spent fuel, loaded into the canister, will be more optimum if it was applied to the spent fuel with $8.2 \%$ FIMA because one canister could be loaded with 1,900 pebbles.

Thus far, Indonesia has adopted the open nuclear fuel cycle option. This indicates that spent fuel is assumed to be a radioactive waste, which requires longterm management. Therefore, this is the right option for the storage of spent fuel in dry storage. Further, the dry storage will reduce the corrosion factor of the spent fuel and its canister. It is crucial to consider the storage safety of the canister, loaded with 1,900 spent-fuel pebbles, for an extended period, encompassing the activity, the decay 
heat, the amount of residual ${ }^{235} \mathrm{U}$ and ${ }^{239} \mathrm{Pu}$ formed and the volatile fission product, ${ }^{137} \mathrm{Cs}$, at various $\%$ FIMAs for storing spent fuel for 100 years. Moreover, higher attention is required for the possible damage of the spent- fuel pebble, especially for the spent fuel with a high $\%$ FIMA. Figure 1 and Table 6 show the effects of \%FIMA on the activity and decay heat of 1,900 of the spent-fuel pebbles in the canister, stored in a dry cask, for 100 years.

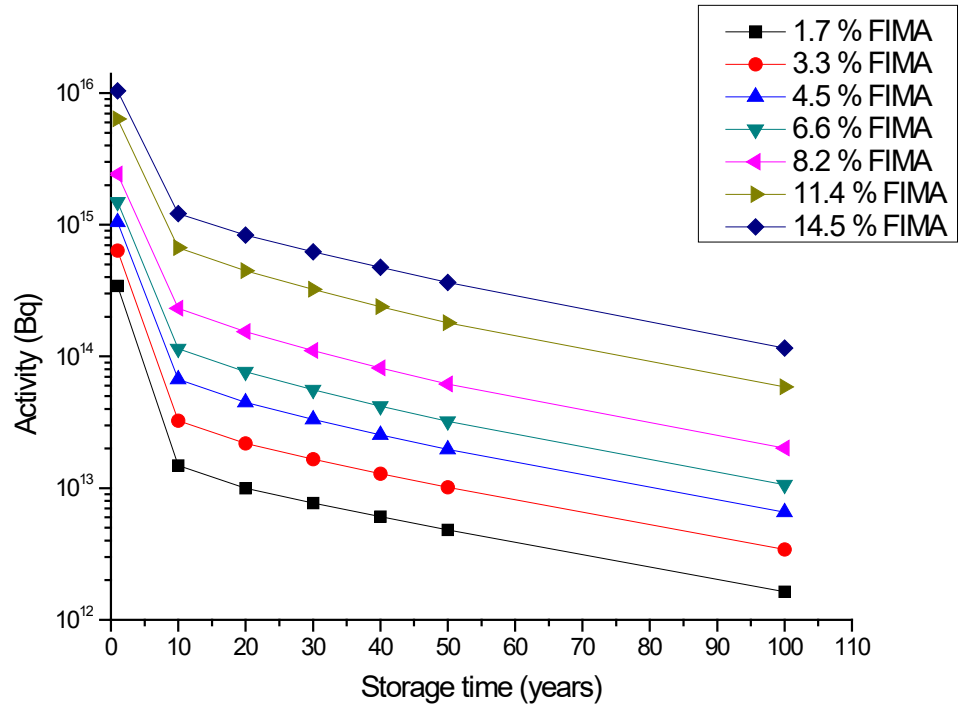

FIGURE 1. Effects of \%FIMA and the storage time on the activity of spent-fuel pebble in the canister

Figure 1 shows the relations between the activity of the spent fuel in the canister, after 100 years of storage, at various \%FIMAs. As observed, there is an average of $99.25 \%$ decrease in the activity. The activity of the fuel in the canister, after 100 years was still of significant value, i.e. $2.013 \times 10^{13} \mathrm{~Bq}$, at $8.2 \% \mathrm{FIMA}$, and this is caused by the presence of an actinide and its daughter, both possessing very long half-lives, and requiring prolonged periods to decay. Compared to the spent fuel that was loaded into the canister with an activity of $4.32 \times 10^{14} \mathrm{~Bq}$ for 1,900 spent-fuel pebbles, after six years of discharge from the reactor, the activity, after 100 years, decreased by a factor of $\sim 21.46$ and so did the decay heats. As shown in Table 6, there was a decrease, which was averagely 3.07 times, after 100 years of storage, at various \%FIMAs.

TABLE 6. Effects of \%FIMA and the storage time on the decay heat of spent fuel in the canister

\begin{tabular}{ccccccc}
\hline \multirow{2}{*}{ \%FIMA burnup } & \multicolumn{7}{c}{ Storage time (year) } \\
\cline { 2 - 7 } & 10 & 20 & 30 & 40 & 50 & 100 \\
\cline { 2 - 7 } & 0.546 & 0.444 & 0.384 & 0.339 & 0.304 & 0.210 \\
3.3 & 1.162 & 0.974 & 0.873 & 0.793 & 0.728 & 0.541 \\
4.5 & 2.290 & 2.017 & 1.893 & 1.783 & 1.685 & 1.352 \\
6.6 & 3.802 & 3.481 & 3.377 & 3.262 & 3.140 & 2.637 \\
8.2 & 7.734 & 7.279 & 7.261 & 7.156 & 6.992 & 6.065 \\
11.4 & 52.409 & 39.900 & 34.128 & 30.040 & 26.964 & 18.905 \\
14.5 & 327.443 & 222.627 & 162.640 & 121.533 & 92.846 & 34.503 \\
\hline
\end{tabular}


At $8.2 \%$ FIMA, the decay heat of the fuel in the canister is $6.065 \mathrm{~W}$ after 100 years of storage. Compared to the spent fuel that was loaded into the canister that exhibited a decay heat of $26 \mathrm{~W}$ with 1,900 spent fuel, at 8.2 \%FIMA, after six years of discharge from the reactor, there is a decrease in the decay heat after 100 years, which was 4.27 times.

\section{PROLIFERATION THREAT}

It is well-known that ${ }^{235} \mathrm{U}$ and ${ }^{239} \mathrm{Pu}$ are fissile radionuclides with the potentials to be distorted into nuclear weapons. ${ }^{239} \mathrm{Pu}$ is normally created in the nuclear reactor by transmutation of ${ }^{238} \mathrm{U}$. The AVR fuel is enriched to $17 \%$, implying that there was as much as $83 \%{ }^{238} \mathrm{U}$. The ${ }^{238} \mathrm{U}$ captured neutrons and transmuted into ${ }^{239} \mathrm{Pu}$ in a process represented as in (2) (Siregar et al. 2016):

$$
{ }_{92}^{238} \mathrm{U}+{ }_{0}^{1} \mathrm{n} \rightarrow{ }_{92}^{239} \mathrm{U} \stackrel{\beta-}{\rightarrow}{ }_{93}^{239} \mathrm{~Np} \stackrel{\beta-}{\rightarrow}{ }_{94}^{239} \mathrm{Pu}
$$

${ }^{238} \mathrm{U}$ captures a neutron and transforms it into ${ }^{239} \mathrm{U}$. The ${ }^{239} \mathrm{U}$ then rapidly undergoes two $\beta^{-}$decays. The first $\beta^{-}$decay transforms the ${ }^{239} \mathrm{U}$ into Neptunium-239, and the second $\beta^{-}$decay transforms the ${ }^{239} \mathrm{~Np}$ into ${ }^{239} \mathrm{Pu}$.

As mentioned, the ${ }^{239} \mathrm{Pu}$ radionuclide is a fissile material that could be utilized as fuel for the nuclear reactor or weapon. Therefore, regarding the proliferation threat, the safety of the spent-fuel storage should be considered in terms of the activity of ${ }^{239} \mathrm{Pu}$, as shown in Figure 2. Figure 2 shows that the spent fuel with high \%FIMA would contain a high ${ }^{239} \mathrm{Pu}$. Therefore, the storage of spent fuel with high \%FIMA should be a dry storage facility with high-safety monitoring.

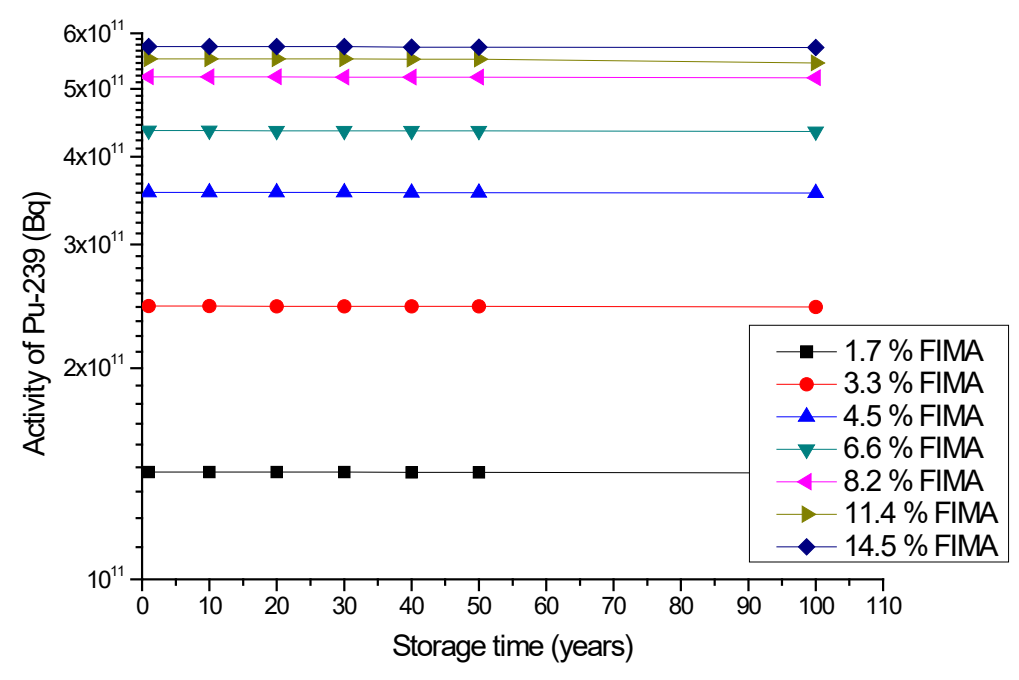

FIGURE 2. Activity of ${ }^{239} \mathrm{Pu}$ in one canister, at various \%FIMA

Figure 2 shows the activity of ${ }^{239} \mathrm{Pu}$ in the canister, loaded with 1,900 spent-fuel pebbles, that increased as $\%$ FIMA increased. However, it appeared to be stable in the storage of 100 years because the half-life of ${ }^{239} \mathrm{Pu}$ is very long, i.e. $2.41 \times 10^{4}$ years. The radionuclides decayed very gradually. Moreover, ${ }^{239} \mathrm{Pu}$ is a radionuclide with a long half-life, which is highly radiotoxic, when it comes in contact with the human body (Aisyah et al. 2019), thus, requiring high-safety levels in terms of its proliferation threat and potential for internal hazard. After 100 years of storage, the activity of ${ }^{239} \mathrm{Pu}$ in the canister, at $8.2 \%$ FIMA, is $5.187 \times 10^{11} \mathrm{~Bq}$. The storage of spent fuel containing a small amount ${ }^{239} \mathrm{Pu}$ could be achieved by the simple dry storage facility than the storage of a high amount of ${ }^{239} \mathrm{Pu}$.

We also considered the presence of ${ }^{235} \mathrm{U}$ in the spent fuel, which originated from the ${ }^{235} \mathrm{U}$ residues, that did not partake in the fission reaction regarding its proliferation. Figure 3 shows the activity of ${ }^{235} \mathrm{U}$ in the canister that was loaded with 1,900 pebbles, at various \%FIMA. 


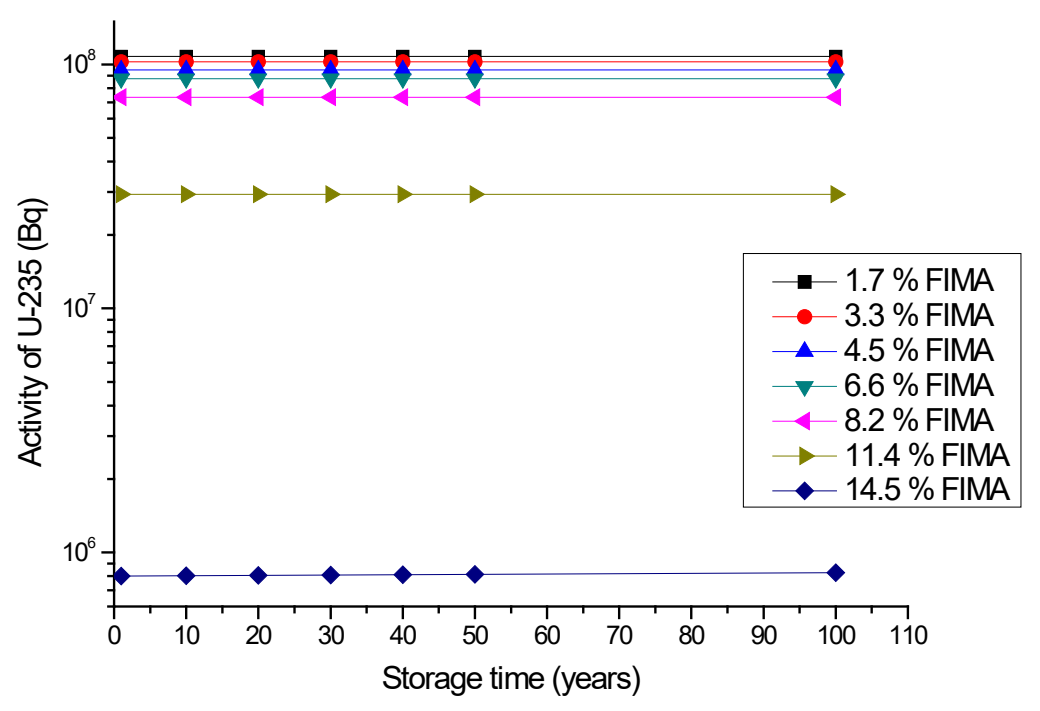

FIGURE 3. Activity of ${ }^{235} \mathrm{U}$ in the Canister, at various \%FIMA

Figure 3 shows that a higher \%FIMA could result in a lower activity of ${ }^{235} \mathrm{U}$ in the spent fuel. However, the activity tends to be stable, after 100 years, because of the extensively long half-life of ${ }^{235} \mathrm{U}$, i.e. $7.04 \times 10^{8}$ years. At 1.7, 3.3, 4.5, 6.6, and 8.2\%FIMA, the activity of ${ }^{235} \mathrm{U}$ tended to be similar to the other, implying that an increase in the duration of the fuel in the reactor core was not optimal to burn ${ }^{235} \mathrm{U}$. However, ${ }^{235} \mathrm{U}$ in the fuel could not be completely burned out. When a significant amount of ${ }^{235} \mathrm{U}$ had already been burned, the number of neutrons generated from the fission reaction could not suffice for the number of neutrons that were captured by ${ }^{238} \mathrm{U}$. Further, as the neutron growth decreased $(k<1)$, the fission reaction in the reactor core stopped. Such a condition could be the reason why ${ }^{235} \mathrm{U}$ is present in the spent fuel (Octadamailah $\&$ Supardjo 2017). The storage of the spent fuel of low $\%$ FIMA would impose an increased risk because of its high ${ }^{235} \mathrm{U}$ content.

Moreover, it is considered uneconomical from the view that the canister could not be loaded maximally. Moreover, a higher \%FIMA would result in smaller ${ }^{235} \mathrm{U}$ residues in the spent fuel, as well as a lowered risk of storing the spent fuel with lower ${ }^{235} \mathrm{U}$ content. Therefore, it was considered economical because of the price of ${ }^{235} \mathrm{U}$. However, a high \%FIMA required the application of high-safety measures regarding the presence of ${ }^{239} \mathrm{Pu}$ and the release of ${ }^{137} \mathrm{Cs}$ to the environment. The calculation result demonstrated that in storing spent fuel, the optimum safety could be achieved at 8.2 \%FIMA with a $7.339 \times 10^{7} \mathrm{~Bq}$ residue of ${ }^{235} \mathrm{U}$

\section{VOLATILE FISSION PRODUCT $\left({ }^{137} \mathrm{Cs}\right)$}

AVR was fueled by nuclear fuels, enriched with $17 \%{ }^{235} \mathrm{U}$. In the operation of AVR, an increased \%FIMA resulted in an increased amount of ${ }^{235} \mathrm{U}$, which would partake in the fission. Accordingly, a higher \%FIMA would also result in the formation of more fission product radionuclides. Conversely, a higher \%FIMA would result in a higher probability that the TRISO coat would be damaged. The primary function of the TRISO coats is to inhibit the release of the formed radionuclides from the spent fuel, especially the volatile products, such as ${ }^{137} \mathrm{Cs}$. These two factors (the formation of more ${ }^{137} \mathrm{Cs}$ and the increased probability of the TRISO coats to damage) increase the tendency of ${ }^{137} \mathrm{Cs}$ to escape from the spent fuel. Therefore, it is crucial to calculate the activity of ${ }^{137} \mathrm{Cs}$ in the canister. The calculation result of the activity of ${ }^{137} \mathrm{Cs}$ in the canister containing 1,900 spent-fuel pebbles indicated an increase, which corresponded to the increase in \%FIMA, as shown in Figure 4. 


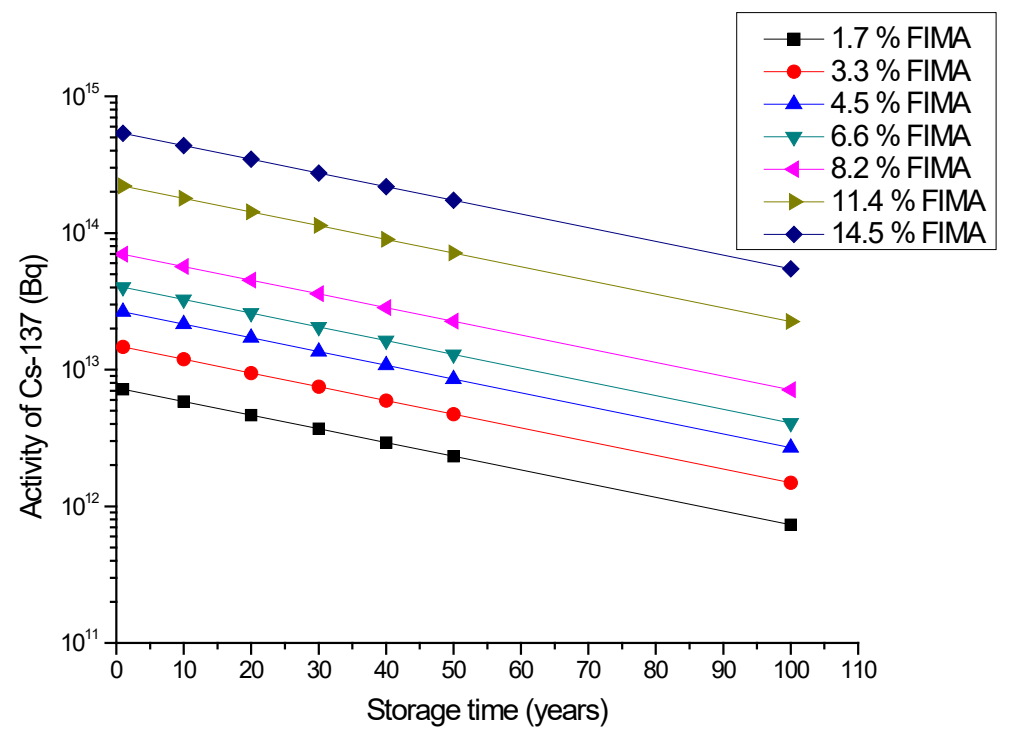

FIGURE 4. Activity of ${ }^{137} \mathrm{Cs}$ in the canister, at various \%FIMAs

Figure 4 indicates that the activity of ${ }^{137} \mathrm{Cs}$ decreased eight-times during 100 years of storing spent fuel, and a similar tendency was observed, at various \%FIMA. This tendency was observed because the half-life of ${ }^{137} \mathrm{Cs}$ was not as long as that of ${ }^{239} \mathrm{Pu}$. Further, a higher \%FIMA corresponded to a higher activity of ${ }^{137} \mathrm{Cs}$ in the spent fuel, as well an increased risk of ${ }^{137} \mathrm{Cs}$ to be released to the environment because of the damaged TRISO coats. The release of the ${ }^{137} \mathrm{Cs}$ radionuclides to the environment endangers human health because of its transmitted gamma radiation. Therefore, one of the methods of maintaining the long-term safety of spent-fuel storage is to optimize the \%FIMA on fuel integrity limits. For a storage duration of 100 years, the activity of ${ }^{137} \mathrm{Cs}$ is $7.100 \times 10^{12}$ Bq, at $8.2 \%$ FIMA.

Regarding the calculation of the storagesafety parameters of the spent fuel, and based on the characterization of its data, the storage of the spent fuel will satisfy the requirements of a characteristic AVR canister and will be optimum, at 8.2\%FIMA, with canister capacity of 1,900 pebbles. This condition satisfied the requirements in terms of the activity and decay heat of the spent fuel that was loaded into the canister. Further, regarding the proliferation due to the presence of ${ }^{239} \mathrm{Pu}$ and ${ }^{235} \mathrm{U}$, the optimum \%FIMA is 8.2 , and so was the presence of ${ }^{137} \mathrm{Cs}$, the fission product, that was released from the canister through the spent fuel, which had damaged its TRISO coats. Therefore, maintaining the fuel integrity was crucial, in terms of the safety of the spent-fuel storage in dry storage, for up to 100 years of storage time.

\section{CONCLUSION}

The long-term storage of AVR spent fuel required the data of the storage-safety parameter, such as the activity, decay heat, proliferation, and ${ }^{137} \mathrm{Cs}$, contained in the spent fuel, at various \%FIMAs. The operation of the reactor with an increased \%FIMA could generate spent fuel with high activity, decay heat, ${ }^{239} \mathrm{Pu}$, and ${ }^{137} \mathrm{Cs}$, thus, ensuring that the loading capacity of the canister of the spent fuel was reduced. Indeed, the high \%FIMA also increased the probability that the TRISO layer of spent fuel could damage, thus, increase the release of ${ }^{137} \mathrm{Cs}$. Therefore, the storage of spent fuel required high monitoring. However, there was a positive feature from the spent fuel with high \%FIMA, i.e. the operation of the reactor was more economical and the spent fuel contained low ${ }^{235} \mathrm{U}$ residue, thereby ensuring a low proliferation risk. Contrarily, at a low \%FIMA, the operation of the reactor generated spent fuel with low activity, decay heat, ${ }^{239} \mathrm{Pu}$, and ${ }^{137} \mathrm{Cs}$, thus the capacity of the canister for loading spent fuel increased, and the storage became more economical. Conversely, the low \%FIMA rendered the operation of the reactor uneconomical and also ensured that the spent fuel contained high ${ }^{235} \mathrm{U}$ residue and high proliferation risk. Based on the choice of storage, the operation of AVR is limited by an optimum \%FIMA of 8.2. 


\section{ACKNOWLEDGEMENTS}

We would like to thank the Center for Radioactive Waste Technology (CRWM), the Ministry of Research and Higher Education under the INSINAS Flagship 2019 Program and Universitas Indonesia under the International Indexed Publication Grant Program (PUTI), Budget Year 2020 (Number: NKB-1700/UN2.RST/HKP.05.00/2020) for their financial support to the study.

\section{REFERENCES}

Aisyah, M., Saputra, D.L.I. \& Setiawan, R. 2019. Characteristization of radionuclides in spent fuel from experimental pebble-bed reactor. Urania 25(1): 45-58.

Artiani, P.A., Ratiko, R., Purwanto, Y. \& Heriyanto, K. 2019. The effect of radiation shielding for dry storage of RDE spent fuels. Jurnal Pengembangan Energi Nuklir 20(2): 83-93.

Center of Radioactive Waste Management (CRWM). 2014. Technical Document of The Study on The Management of Radioactive Waste from RDE HTR-10 Type. 10.

Demkowicz, P.A., Liu, B. \& Hunn, J.D. 2019. Coated particle fuel: Historical perspectives and current progress. Journal of Nuclear Materials 515: 434-450.

Dewita, E. 2008. Pengembangan partikel bahan bakar berlapis untuk reaktor VHTR. Jurnal Pengembangan Energi Nuklir 10(2): 113-122.

Dulera, I.V., Sinha, R.K., Rao, A.R. \& Patel, R.J. 2017. High temperature reactor technology development in India. Progress in Nuclear Energy 101: 82-99.

Gil, C.S., Kim, D.H., Yoo, J.K. \& Lee, J. 2017. Fission yields data generation and benchmarks of decay heat estimation of a nuclear fuel. EPJ Web of Conferences 146: 04048.

Hadad, K., Nematolahi, M. \& Golestani, A. 2015. VVER-1000 cross-section library generation for ORIGEN-II based on MCNP calculations. International Journal of Hydrogen Energy 40(44): 15158-15163.

Husnayani, I. 2015. Calculation of radionuclide content of nuclear materials using ORIGEN 2.1 computer code. Sigma Epsilon-Buletin Ilmiah Teknologi Keselamatan Reaktor 19(1): 20-25.

Husnayani, I. \& Udiyani, P.M. 2018. Radionuclide characteristics of RDE spent fuels. Jurnal Teknologi Reaktor Nuklir Tri Dasa Mega 20(2): 69-76.

Ji, W., Liang, C. \& Pusateri, E.N. 2014. Analytical dancoff factor evaluations for reactor designs loaded with TRISO particle fuel. Annals of Nuclear Energy 63: 665-673.

Kania, M.J., Nabielek, H., Verfondern, K. \& Allelein, H.J. 2013. Testing of HTR UO2 TRISO fuels in AVR and in material test reactors. Journal of Nuclear Materials 441(13): 545-562.

Kim, J.S., Jeon, Y.S., Dal Park, S., Ha, Y.K. \& Song, K. 2015. Analysis of high burnup pressurized water reactor fuel using uranium, plutonium, neodymium, and cesium isotope correlations with burnup. Nuclear Engineering and Technology 47(7): 924-933.
Liem, P.H., Sembiring, T.M. \& Tran, H.N. 2018. Evaluation on fuel cycle and loading scheme of the Indonesian experimental power reactor (RDE) design. Nuclear Engineering and Design 340: 245-259.

Liem, P.H., Tran, H.N., Sembiring, T.M., Arbie, B. \& Subki, I. 2017. Alternative fueling scheme for the Indonesian experimental power reactor (10 MWth Pebble-Bed HTGR). Energy Procedia 131: 69-76.

Octadamailah, S. \& Supardjo. 2017. Effect of uranium density on nuclear fuel life time and burn up in RSG- GAS reactor from a neutronic point of view. Urania Jurnal Ilmiah Daur Bahan Bakar Nuklir 23(2): 117-126.

Prasad, S., Abdulla, A., Morgan, M.G. \& Azevedo, I.L. 2015. Nonproliferation improvements and challenges presented by small modular reactors. Progress in Nuclear Energy 80 : 102-109.

Pratomo, H.B. 2017. The demand of nuclear power plant in the world will keep increasing in the future. https://www. merdeka.com/uang/kebutuhan-dunia-pada-pembangkitnuklir-terus-meningkat-di-masa-depan.html. Access on 20 December 2019

Ratiko, R., Wisnubroto, D.S., Nasruddin, N. \& Mahlia, T.M.I 2020. Current and future strategies for spent nuclear fuel management in Indonesia. Energy Strategy Reviews 32: 100575.

Ratiko, R., Moriizumi, J., Yamazawa, H. \& Nasruddin, N. 2019. Quantification of the impact of temperature difference between two connected indoor spaces on $222 \mathrm{Rn}$ concentration. Building and Environment 149: 322-329.

Ratiko, R., Samudera, S.A., Hindami, R., Siahaan, A.T., Naldi, L., Hapsari, D., Mahlia, T.M.I. \& Nasruddin, N. 2018. Optimization of dry storage for spent fuel from G.A. Siwabessy nuclear research reactor. International Journal of Tecnology 9(1): 55-67.

Sartori, E. 2013. Nuclear data for radioactive waste management. Annals of Nuclear Energy 62: 579-589.

Sen, R.S. \& Viljoen, C.F. 2012. The re-evaluation of the AVR melt-wire experiment with specific focus on different modeling strategies and simplifications. Nuclear Engineering and Design 251: 306-316.

Serfontein, D.E., Mulder, E.J. \& Reitsma, F. 2014. Assessment and reduction of proliferation risk of reactor-grade plutonium regarding construction of 'fizzle bombs' by terrorists. Nuclear Engineering and Design 271: 545-551.

Setiadipura, T., Irwanto, D. \& Zuhair, Z. 2015. Preliminary neutronic design of high burnup OTTO cycle pebble bed reactor. Atom Indonesia 41(1): 7-15.

Setiadipura, T., Bakhri, S., Sunaryo, G.R. \& Wisnusubroto, D.S. 2018. Cooling passive safety features of reaktor daya eksperimental. AIP Conference Proceedings 1984(1): 020034-1-9.

Siregar, I.H., Frida, A.R., Suharyana, Khakim, A. \& Siregar, D. 2016. Calculation on maximum accumulation of $\mathrm{Pu}-239$ and $\mathrm{Pu}-241$ from aqueous homogeneous reactor. Proceedings of The Meeting and Scientific Presentations on Basic Science Research and Nuclear Technology. pp. 169-173. 
Ternovykh, M., Tikhomirov, G., Saldikov, I. \& Gerasimov, A. 2017. Decay heat power of spent nuclear fuel of power reactors with high burnup at long-term storage. EPJ Web of Conferences 153(07035): 1-6.

Verfondern, Karl. n.d. AVR decommissioning. In IAEA Mission to PTLR-BATAN on HTGR Decommissioning and Waste, Jakarta, Indonesia, May 15-19, 2017.

Wang, J.H., Huang, Y.F., Tang, Y. \& Wu, B. 2013. Natural safety analysis of the spent fuel residual heat removal in loading and storage process of HTR-10. Energy Procedia 39: 227-239.

Wang, S. \& Yang, B.W. 2017. Numerical investigation on thermal hydraulic and transit time characteristics of density wave oscillations. Energy Procedia 127: 291-301.

Wu, S.C., Chao, D.S. \& Liang, J.H. 2019. A study of burnup credit in criticality safety analysis for PBR spent fuel pebbles. Annals of Nuclear Energy 132: 347-356.
Aisyah Aisyah, Mirawaty Mirawaty, Dwi Luhur Ibnu Saputra, Risdiyana Setiawan, Pungky Ayu Artian \& Ratiko Ratiko* Center for Radioactive Waste Technology (PTLR)

National Nuclear Energy Agency of Indonesia (BATAN) Indonesia

\section{Nasruddin Nasruddin}

Department of Mechanical Engineering

Universitas Indonesia

Indonesia

*Corresponding author; email: ratiko_ratiko@yahoo.com

Received: 17 February 2020

Accepted: 22 July 2020 